Copyright (C) 2018 by Academic Publishing House Researcher

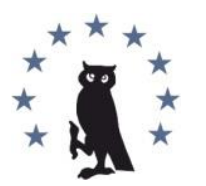

Published in the Russian Federation

European Researcher. Series A

Has been issued since 2010.

ISSN 2219-8229

E-ISSN 2224-0136

2018, 9(2): 68-77

DOI: 10.13187/er.2018.2.68

www.erjournal.ru

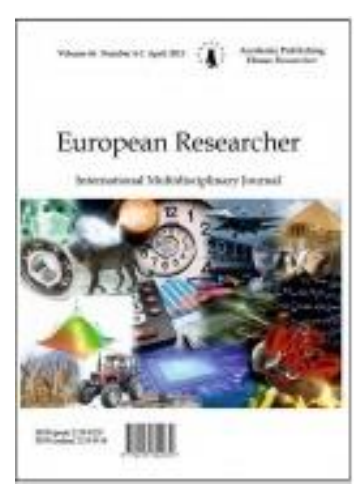

\title{
Intercultural Development of Bosnian University Students Through Foreign Language Learning
}

\author{
Senad Bećirović ${ }^{a},{ }^{*}$, Suraja Podojak ${ }^{\text {a }}$ \\ ${ }^{a}$ International Burch University, Bosnia and Herzegovina
}

\begin{abstract}
As human beings, we are aware of the constant changes that world is experiencing rather rapidly. Technology has an important impact on our present and very likely on our future as well. The population flow is increasing, caused by different reasons such as jobs, family, better future outlook etc. As a person moves, so their culture changes, willingly or not. In majority of cases, moving to another place forces a person to adapt to new cultures and that also includes learning the target culture's language. It is argued by many experts that through the learning of a new language a person can become very familiar with the culture itself. In that process, a certain filter is needed that will keep balance and minimize conflicts between the "old" and the "new" culture of an individual. That filter is intercultural education. The aim of this research was to determine the extent to which intercultural education has been established in tertiary education in Bosnia and Herzegovina through Foreign Language Learning. The instrument used for this research consists of 50 questions comprising four subscales: intellectual flexibility, interaction engagement, interaction confidence, and attitudes. The research sample consists of 160 students from three universities in Bosnia and Herzegovina two of which are private universities and one state university. The results show that the type of the university, students' educational level, and gender significantly affect their intercultural development. The significance of the findings of this study lies in the fact that they might be employed during the process of planning and execution of foreign language teaching and learning steps.
\end{abstract}

Keywords: culture, education, communication, language.

\section{Introduction}

The importance of being able to speak a foreign language is increasing constantly and knowing a foreign language has become a necessity rather than a recommendation for both old and new generations (Rizvić, Bećirović, 2017). More and more people are interested in or even forced to learn one or several different languages. Whether we want it or not, knowledge of foreign languages is becoming one of the main components of survival in the current globalized world. According to Sercu (2005), majority of employers want their employees to know at least one language other than their native language and people who know several foreign languages are generally preferred in today's business world.

When someone is learning a foreign language that means they are connected to a world different from their own in terms of culture (Sercu, 2005). According to Bećirović (2012), schools

\footnotetext{
${ }^{*}$ Corresponding author

E-mail addresses: senad.becirovic@ibu.edu.ba (S. Bećirović), surajjapodojak@gmail.com (S. Podojak)
} 
ought to support children in learning about other cultures and enable them to respect and accept those who are culturally different. Teachers should be able to recognize the importance of educating young people (Delić, Bećirović, 2016). In contexts where international understanding represents the key for being able to communicate with people that are culturally different (Salgur, 2013). Bećirović (2017) claimed that, by learning a foreign language, students develop appreciation for the target culture and language, meaning that a person is therefore completely seeing themself as a part of the target society and they are able to learn a new language and accept the other culture with utmost pleasure. Learning a new language has now become a rule and an obligation in many schools around the world.

As Salgur puts it (2013), teachers could develop intercultural understanding by making their students use tools such as different events that happened in the past, events that are happening in the present and those that are expected to take place in the future. The relationship between students is extremely important in intercultural education - namely, as they interact with each other, they have the opportunity to recognize similarities and differences between them and develop respect toward those who are different (Bećirović, 2012). Smokova (2010) suggested that by encouraging the development of intercultural competences in students the educators have an opportunity to teach them how to live alongside people from other cultural backgrounds. By communicating with people from different cultures students can learn about different lifestyles, values, histories and habits (Neuliep, 2005). According to Bećirović (2012), it is not enough solely to know something about someone's culture - students should be able to develop sympathy toward them as well. Even when someone believes that their culture is different from other cultures, they all have a lot in common because we as humans have similar desires and needs (Neuliep, 2005).

The results of this research may help policy makers and implementers in ministries, schools, universities and other language learning institutions to create better conditions and environment for intercultural development. Moreover, by studying the results of this research, educators can prepare themselves for and help their students cope with all the new challenges that different cultural backgrounds bring to the teaching and learning process.

\section{Review of literature}

2.1. What is culture and what is intercultural education?

The National Center for Cultural Competence defined culture as "an integrated pattern of human behavior that includes thoughts, communication, languages, practices, beliefs, values, customs, courtesies, rituals, manners of interacting and roles, relationships and expected behaviors of a racial, ethnic, religious or social group; and the ability to transmit the above to succeeding generations" (Martinson, Schulz, 2008: 92).

UNESCO (2002, p.4), defines culture as "a set of distinctive spiritual, material, intercultural, and emotional patterns of a society or group of people, along with their art, literature, lifestyles and ways of living together, value system, traditions and beliefs". According to Savić (2013), language is culture - that is because while learning a new language the learners also learn about the culture that the target language belongs to.

Other definitions of culture include those by Neuliep (2005, p.21) stating that "culture is an accumulated pattern of values, beliefs, and behaviors, shared by an identifiable group of people with a common history and verbal and nonverbal symbol systems" and the one by Baungartl and Milojević (2009, p. 91) claiming that "culture is what defines us or how we define ourselves and what we identify with; what is giving us an orientation in the world, the set of categories which make sense out of raw material which we receive through our senses".

In line with the definition of culture, the definition of intercultural education states that it is "a form of education which respects, celebrates and recognizes the normality of diversity in all areas of human life. It sensitizes the learner to the idea that humans have naturally developed a range of different ways of life, customs and worldviews, and that this breadth of human life enriches all of us" (National Council for Curriculum and Assessment, 2006: 1).

Birzea (2006, p.7) distinguishes between three levels of intercultural education: "the level of educational policies in the form of clear-cut educational aims and purposes, the level of institutions, student participation, open learning settings and inclusive policies, and the teaching level, through approaches and methods". 
According to Neuliep (2005), belonging to a specific racial, ethnic, sex or age group does not necessarily imply the acquisition of thoughts, behaviors and attitudes of that group. Perroti (1994) believes that the main goal of intercultural education is to develop generations of students who will be active members of their respective social groups and other cultural groups by the means of "new ideas in history, geography, language, culture, philosophy, humanity and society" (Zilliacus, Holm, 2009: 11).

As for the objectives of intercultural education, Chiriac and Panciuc (2015, p.1) believe that educators and policy makers should strive for the following:

- Enhancing the efficiency of intercultural relations

- Increasing tolerance and acceptance toward those who are different

- Training people to make them perceive, accept and respect diversity for mediating social relations

The importance of culture today is perhaps best summarized in words by Tyeb (2000), who said that "culture is like air. It is everywhere, we cannot see it, but we feel it, we know it is there, and we cannot exist without it" (Dadfar, 2001: 14).

2.2. Why is it important to be interculturally educated?

Intercultural competencies are necessary for overcoming societal and national differences (Bećirović, 2012). Intercultural education helps people from different cultures to understand each other. According to Biagioli (2005), in a world full of diversities and similarities between people intercultural education exists to build stronger and better ties between people with high-quality knowledge about other cultures. Salgur (2013) believes that intercultural education helps in overcoming problems related to inequity, discrimination, ethnic/cultural diversity and citizenship. As Patrascu and Allam put it (2015 p. 284) "intercultural education can provide the opportunities to study the cultures of the world and facilitate the understanding among civilizations which could strengthen the making of a global world".

Diplo Foundation (2016) believes that having not enough knowledge about other cultures can cause many misunderstandings in interpersonal and intergroup communication. In order to live together peacefully, education must be a basic step in coping with challenges that cultural and religious diversities represent (Milot, 2006). Neuliep (2005) claims that mass migrations that we witness in the world today are forcing people to interact with people of different races, nationalities, and ethnicities as common goals bring these people together. Only being well interculturaly educated and having intercultural competencies can reduce discrimination. According to Bećirović (2016), intercultural education develops competencies to treat all people equally - teachers, students, adolescents, foreign students and immigrants - regardless of their differences.

Qin (2014) claims that when a person encounters another culture for the first time they recognize lots of things that are interesting and different from their own culture. According to Neuliep (2005), through communication it is possible to manage and resolve all conflicts, local, regional, national and international. Intercultural communication can make people work together and achieve significant personal and professional goals. Neuliep (2005, p. 4.) believes that "the benefits of intercultural education are:

1. Healthier Communities;

2. Increased Commerce;

3. $\quad$ Reduced Conflict;

4. Personal Growth through tolerance".

Intercultural education offers a helping hand in learning how to appreciate cultures of others, understand the essence of other cultures with dialogues and discussions among various cultures (Patrascu, Allam, 2015). According to Rajić and Prtljaga (2013), we should be aware that today's world is giving us opportunities for cooperation where we can decrease distance between each other and increase tolerance, because "only as culturally aware beings, defined in a cultural way, can we discover, meet, and reject or appreciate others' differences" (Baungartl, Milojević, 2009: 92). Intercultural communication is important for the society in general as it manages many conflicts that arise as a consequence of incompetence of certain people to recognize and accept other people's point of view (Neuliep, 2005). 
2.3. Foreign language learning as a way of development intercultural competencies

"Language is one of the most universal and diverse forms of expression of human culture. It is at the heart of issues of identity, memory and transmission of knowledge" (UNESCO, 2009: 13). For learners, a new language in the classroom is something that connects their world with something that they may have never heard of or experienced before (Sercu, 2005).

According to Neuliep (2005 m p. 15), "the most obvious verbal communication difference between two cultures is language". While teaching a language, the teacher's responsibility is to prepare learners for different backgrounds that they will encounter during the process of learning a new language (Byram, Wagner, 2017). Bachman (1990) suggested that in order to learn a language we should also be ready to learn about the culture of that language. According to Gualandi (2015), cultural diversity is taking precedence in modern classrooms. Krieger (2005) believes that students' first encounter with the new language should occur in the early age, through school programs. By meeting their first foreign language young learners also meet their first new culture (Yaman, Bećirović, 2016).

Byram and Wagner (2017, p. 148) mention how "it is difficult to learn a language especially when this means using it in real time for communication, whether written or spoken" According to Bećirović (2012), teachers and parents are the most important people in these early developmental stages, given that children almost always follow them in creating their identities. Jarcau (2014) believes that intercultural education should start in the family first and then school should continue with this approach. Ryan and Sercu (2005) believe that foreign language teachers should have abilities close to the native speakers, which means being able to use foreign language, explain the subject matter to the students and encourage students' learning. Schools should be able to offer to their students an international environment with a tolerant atmosphere that will help them understand differences between cultures and show them what it is like to co-live with someone who comes from a different cultural background (Smokova, 2010).

Liddicoat and Scarino (2005) believe that, in order to learn language, "intercultural competence is a necessity and intercultural competence includes:

- Accepting that one's own and others' behavior is culturally determined;

- Accepting that there is no one right way to do things;

- Valuing one's own culture and other cultures;

- Using language to explore culture;

- Finding personal solutions in intercultural interaction;

- Using L1 culture as a resource to learn about L2 culture;

- Finding an intercultural style and identity" (Liddicoat, Scarino, 2005: 3).

Evans (1988, p. 22) argues that "learning a new language means creating a new identity irrespective of the foreign culture or foreign experience”. According to Baungartl, Milojević (2009), while learning new language we are becoming more interculturally competent, meaning that with every new language our intercultural competence grows. Suchankova (2014, p.1439) claims that language education helps a person "form their own opinion, helps them travel, become acquainted with other cultures, and broaden their perspective". If an individual possesses good linguistic skills but not enough cultural knowledge about that language, many misunderstandings may arise (Qin, 2014). Bennet and Allen (2003, p. 237) claim that "the person who learns language without learning culture risks becoming a fluent fool”.

\section{Methodology}

The aim of this research was to measure the extent to which factors such as university type, gender, age, educational level and the number of foreign languages in use affect the intercultural development of students studying English Language and Literature in Bosnian-Herzegovinian tertiary education.

The following hypotheses have been tested:

1. Intercultural development will differ by university type and gender when controlling for age influence. Furthermore, we hypothesize there will be a significant interaction effect of the university type $\mathrm{x}$ gender on intercultural development when controlling for age influence.

2. Combined dependent variables of intercultural development will significantly differ by 
educational level.

3. Combined dependent variables of intercultural development will significantly differ by the foreign language usage.

3.1. Participants

The sample for this study consists of 160 students from three universities - two universities from Sarajevo and one university from Zenica, Bosnia and Herzegovina. Of the total number of participants, 67 students are from the University of Zenica, 40 students are from the International University of Sarajevo and 53 students are from the International Burch University. All students study at different educational levels, including freshman, sophomore, junior, senior and master students. All students study at English Language and Literature departments. Out of 160 students, 67 are male and 96 are female students, and in terms of nationalities there are 125 participants of Bosnian-Herzegovinian nationality, 28 Turkish students and 7 students who have reported other nationalities.

Table 1. Descriptive analysis of participants

\begin{tabular}{llcc}
\hline & & N & Percent \\
\hline University & IBU & 88 & 40.2 \\
& UNZE & 62 & 28.3 \\
Type of university & IUS & 69 & 31.5 \\
& State & 62 & 28.3 \\
& Private & 157 & 71.7 \\
Nationality & Bosnian & 125 & 57.1 \\
& Turkish & 78 & 35.6 \\
Gender & Others & 16 & 7.3 \\
Grade level & Female & 121 & 55.3 \\
& Male & 98 & 44.7 \\
& Freshman & 55 & 25.1 \\
& Sophomore & 42 & 19.2 \\
\multirow{5}{*}{ Foreign languages } & 38 & 17.4 \\
in use & Junior & 60 & 27.4 \\
& Senior & 24 & 11 \\
& Master & 90 & 62.9 \\
& English as foreign & & \\
& language & 53 & 37.1 \\
& More than one foreign & 219 & 100 \\
\hline
\end{tabular}

3.2. Instruments and procedure

The research instrument, developed and validated by the authors, comprises 50 questions distributed to the students of three different universities in Bosnia and Herzegovina - two private and one state university. A five-point Likert scale is used in questionnaires, with points being as follows: strongly agree, agree, neutral, disagree, and strongly disagree with the statements. The items in the instrument have been divided into four scales of the intercultural development including intellectual flexibility $(\alpha=0.69)$, interaction engagement $(\alpha=0.69)$, interaction confidence $(\alpha=0.85)$, and intercultural attitudes $(\alpha=0.59)$. Crombach's alpha internal consistency measure was used $(\alpha=0.88)$ for all items in the instrument. Participants completed their surveys during their lesson time, with permission of their lecturer. They needed 45 minutes to complete surveys. All the questionnaire statements were written in English language.

3.3. Data analysis

In order to analyze the data collected, the Statistical Package for Social Sciences (SPSS) version .22 was used. ANCOVA, ANOVA, MANOVA and Tukey HSD tests were employed to measure differences in intercultural development between different groups. 


\section{Results}

4.1. The effect of university type and gender on intercultural development when controlling age

A 2 x 2 analysis of covariance was conducted to determine the effect of university type and gender on intercultural development when controlling age. Independent variables consisted of university type (private and state) and gender (male and female). The covariate was age. Intercultural development varied significantly by gender $F(1,138)=4.20, p=.042, \eta^{2}=.030$. Table 2 presents the summary of ANCOVA results. Comparison of adjusted group means, as displayed in Table 3, reveals that female students express better intercultural development than male students. Intercultural development did not vary significantly in terms of university status $F$ $(1,138)=3.74, p=.055, \eta^{2}=.026$. Comparison of adjusted group means, as displayed in Table 3 , reveals that intercultural development is more advanced on private universities. However, the aforementioned difference is insignificant. The interaction effect gender X university type was insignificant $F(3,138)=.22, p=.642, \eta^{2}=.002$. The covariate of age also did not significantly influence the dependent variable of intercultural development $F(1,138)=.013, p=.909$, $\eta^{2}=.000$.

Table 2. ANCOVA results

\begin{tabular}{|c|c|c|c|c|c|c|}
\hline Source & $S S$ & $d f$ & MS & $\boldsymbol{F}$ & $\boldsymbol{P}$ & $\eta^{2}$ \\
\hline Corrected Model & $.798^{a}$ & 4 & .199 & 1.991 & .099 & .055 \\
\hline Intercept & 19.234 & 1 & 19.234 & 192.023 & .000 & .582 \\
\hline Age & .001 & 1 & .001 & .013 & .909 & .000 \\
\hline University type & .375 & 1 & .375 & $3 \cdot 740$ & .055 & .026 \\
\hline Gender & .421 & 1 & .421 & 4203 & .042 & .030 \\
\hline $\begin{array}{l}\text { University type * } \\
\text { Gender }\end{array}$ & .022 & 1 & .022 & .217 & .642 & .002 \\
\hline Error & 13.823 & 138 & .100 & & & \\
\hline Total & 2324.004 & 143 & & & & \\
\hline Corrected Total & 14.621 & 142 & & & & \\
\hline
\end{tabular}

Table 3. Adjusted and unadjusted group means for intercultural development by university status and gender

\begin{tabular}{lcc}
\hline Variables & Adjusted $\boldsymbol{M}$ & Unadjusted $\boldsymbol{M}$ \\
\hline State University & 3.96 & 3.96 \\
Private University & 4.06 & 4.07 \\
Female students & 4.06 & 4.07 \\
Male students & 3.95 & 3.96 \\
\hline
\end{tabular}

4.2. The relationship between educational level and intercultural development

A MANOVA was used to examine the relationship between educational level as independent variable, and intercultural development and its subscales namely intellectual flexibility, interaction engagement, interaction confidence, and attitudes as DVs. MANOVA results showed that educational level statistically affects combined variables of intercultural development Wilks' Lambda $\lambda=0.76, F(15,373)=2.59, p=.001, \eta^{2}=.087$. The effect size is moderate. Univariate ANOVA and Tukey HSD post hoc test were employed as follow up tests and indicated that educational level significantly affects intellectual flexibility $F(3,139)=5.46, p=.001, \eta^{2}=.105$ and total intercultural development $F(3,139)=3.28, p=.023, \eta^{2}=.066$ and both effect sizes are 
moderate. Educational level does not significantly affect interaction engagement $F(3,139)=2.11, p$ $=.102, \eta^{2}=.044$, interaction confidence $F(3,139)=1.78, p=.153, \eta^{2}=.037$ and attitudes $F(3$, 139) $=2.08, p=.106, \eta^{2}=.043$. Tukey HSD post hoc results for intellectual flexibility indicated that freshmen and sophomore and freshmen and senior students significantly differ and in terms of total intercultural development freshmen and sophomore students significantly differ.

Table 4. Adjusted and unadjusted means for intercultural development by educational level

\begin{tabular}{lcccccccccc}
\hline & \multicolumn{2}{c}{$\begin{array}{c}\text { Intellectual } \\
\text { flexibility }\end{array}$} & \multicolumn{2}{c}{$\begin{array}{c}\text { Interaction } \\
\text { Engagement }\end{array}$} & \multicolumn{2}{c}{$\begin{array}{c}\text { Interaction } \\
\text { confidence }\end{array}$} & \multicolumn{2}{c}{ Attitudes } & \multicolumn{2}{c}{ Total } \\
\cline { 2 - 5 } & Adj. & Unad. & Adj. & Unad. $M$ & Adj. & Unad. & Adj. & Unad. & Adj. & Unad. \\
Freshman & $M$ & $M$ & $M$ & & $M$ & $M$ & $M$ & $M$ & $M$ & $M$ \\
& 3.73 & 3.72 & 3.78 & 3.78 & 4.33 & 4.32 & 4.03 & 4.03 & 3.90 & 3.90 \\
Sophomore & 4.11 & 4.10 & 3.87 & 3.87 & 4.46 & 4.46 & 4.26 & 4.26 & 4.10 & 4.10 \\
Junior & 3.96 & 3.95 & 3.78 & 3.78 & 4.23 & 4.22 & 4.21 & 4.21 & 3.97 & 3.97 \\
Senior & 4.08 & 4.08 & 3.97 & 3.97 & 4.26 & 4.25 & 4.14 & 4.14 & 4.08 & 4.08 \\
\hline
\end{tabular}

4.3. The relationship between usage of foreign languages and intercultural development

A MANOVA was also conducted to examine the relationship between the usage of foreign languages as an independent variable, and intercultural development and its subscales namely intellectual flexibility, interaction engagement, interaction confidence and attitudes as DVs. The independent variable usage of foreign languages included two levels; one is using English as a foreign language and second was using more than one foreign language. MANOVA results showed that the usage of foreign languages significantly affects combined variables of intercultural development Wilks' Lambda $\lambda=0.92, F(5,137)=2.35, p=.044, \eta^{2}=.079$. The effect size is moderate. Univariate ANOVA was employed as a follow up test and it indicated that the usage of foreign languages significantly affects interaction engagement $F(1,141)=6.63, p=.011, \eta^{2}=.45$, interaction confidence $F(1,141)=5.23, p=.024, \eta^{2}=.036$, attitudes $F(1,141)=6.57, p=.011, \eta^{2}$ $=.45$ and total intercultural development $F(1,141)=7.10, p=.009, \eta^{2}=.48$, while it does not significantly affect intellectual flexibility $F(1,141)=0.56, p=.454, \eta^{2}=.004$.

Table 5. Adjusted and unadjusted means for intercultural development by the usage of foreign languages (FL)

\begin{tabular}{|c|c|c|c|c|c|c|c|c|c|c|}
\hline & \multicolumn{2}{|c|}{$\begin{array}{l}\text { Intellectual } \\
\text { flexibility }\end{array}$} & \multicolumn{2}{|c|}{$\begin{array}{l}\text { Interaction } \\
\text { Engagement }\end{array}$} & \multicolumn{2}{|c|}{$\begin{array}{l}\text { Interaction } \\
\text { confidence }\end{array}$} & \multicolumn{2}{|c|}{ Attitudes } & \multicolumn{2}{|c|}{ Total } \\
\hline & $\begin{array}{c}\text { Adj. } \\
M\end{array}$ & $\begin{array}{c}\text { Unad. } \\
M\end{array}$ & $\begin{array}{c}\text { Adj. } \\
M\end{array}$ & $\begin{array}{c}\text { Unad. } \\
M\end{array}$ & $\begin{array}{c}\text { Adj. } \\
M\end{array}$ & $\begin{array}{c}\text { Unad. } \\
M\end{array}$ & $\begin{array}{c}\text { Adj. } \\
M\end{array}$ & $\begin{array}{c}\text { Unad } \\
. M\end{array}$ & $\begin{array}{c}\text { Adj. } \\
M\end{array}$ & $\begin{array}{c}\text { Unad. } \\
M\end{array}$ \\
\hline English as a FL & 3.96 & 3.96 & 3.79 & 3.79 & 4.26 & 4.26 & 4.11 & 4.10 & 3.97 & 3.96 \\
\hline $\begin{array}{l}\text { More than one } \\
\text { FL }\end{array}$ & 4.02 & 4.02 & 3.96 & 3.96 & 4.44 & 4.44 & 4.28 & 4.28 & 4.11 & 4.11 \\
\hline
\end{tabular}

\section{Discussion and conclusion}

This study investigated the effect of university type, educational level, and gender on intercultural development in the process of learning of English as a foreign language.

The first hypothesis stated that intercultural development will differ by the university type and gender when controlling for age influence. The study sample consisted of two types of universities, state and private, and both male and female participants. According to the results, intercultural development is insignificantly more advanced on private universities. This result could be expected because at private universities students have a better chance to meet international students and international professors coming from different cultures, to hear different languages all while communicating with those people in English language as the medium 
of instruction. However, intercultural development varied significantly by gender. Female students express better intercultural development than male students. Covariate age didn't significantly influence on dependent variable of intercultural development. Similarly, Narayanan (2007) found that female students are more interested in learning foreign languages and male students are less motivated. According to the results of a study conducted by Heinzmann (2009), girls are significantly more motivated to learn English than boys and they enjoy lessons more and make fewer mistakes while learning. Solhaug, Kristensen (2016) reached similar conclusions, claiming that girls have higher intercultural competence than male students.

The second hypothesis stated that combined dependent variables of intercultural development will significantly differ by educational level. This hypothesis has been supported. Results showed that educational level significantly affects combined variables of intercultural development. Educational level significantly affects total intercultural development and intellectual flexibility, while it does not affect interaction engagement, interaction confidence and intercultural attitudes. Results showed that students of first and second year significantly differ from fourth year students. Furthermore, sophomore students showed the lowest level of intercultural development.

The last hypothesis in this study stated that combined dependent variables of intercultural development will significantly differ by the foreign language usage. This hypothesis has been supported. According to the results, the usage of foreign languages significantly affects combined variables of intercultural development. Univarate ANOVA showed that usage of foreign language significantly affects total intercultural development, interaction engagement, interaction confidence, and intercultural attitudes, whereas it does not significantly affect Intellectual flexibility. According to the results there is significant difference in the intercultural development between students that are speaking only English as a foreign language and students that are able to speak more than one foreign language. The students who use more foreign languages showed significantly higher level of intercultural development. The results of this research are similar to the findings of Rajić, Prljaga (2013). They also found that learning foreign languages influences intercultural development.

As human beings, with all our differences and similarities, we should strive for better relations between people (Piršl, 2011). We all have the same rights, regardless of our nationality, religion, language or skin color (Farena, 2016). As Dadfar (2001, p. 14) mindfully puts it, "if we are to understand man - his action, reaction, behavior - we must seek to understand his culture". Hence, it is very important to develop intercultural education which will help the society in general by enabling people to better understand each other.

\section{References}

Baungartl, Milojević, 2009 - Baungartl, B., Milojević M. (2009). Interculturality a necessary skill in the $21^{\text {st }}$ century. In T.A. Odina \& M. Del Olmo (Eds.) Intercultural Education perspectives and proposals, pp. 89-103.

Bećirović, 2012 - Bećirović, S. (2012). The Role of Intercultural Education in Fostering Cross-Cultural Understanding. // Epiphany Journal of transdisciplinary studies. Vol.5, No.1, (pp.138-156). DOI: http://dx.doi.org/10.21533/epiphany.v5i1.49

Bećirović, 2016 - Bećirović, S. (2016). Development of Intercultural Education through English language textbooks used in elementary schools in B\&H. In A. Akbarov (Ed.). Current Research On Language Learning and Teaching (pp. 245-259). Cambridge Scholars Publishing.

Bećirović, 2017 - Bećirović, S. (2017). The Relationship between Gender, Motivation and Achievement in Learning English as a Foreign Language. // European Journal of Contemporary Education (pp. 210-219). DOI: 10.13187/ejced.2017.2.210

Birzea, 2006 - Birzea, C. (2006). The education policy perspective. In J. Keast (Ed.). Religious diversity and intercultural education: a reference book for schools, pp.7-8. Council of Europe.

Byram et al., 2002 - Byram, M., Gribkova B., Starkey H. (2002). Developing the Intercultural dimension in language teaching. Councile of Europe. Strasbourg.

Byram, Wagner, 2017 - Byram, M., Wagner M. (2017). Making a difference: Language teaching for intercultural and international dialogue. In Foreign Language Annals, pp. 140-151. 
Chiriac, Panciuc, 2015 - Chiriac, A., Panciuc L. (2015). Intercultural Education- Objectives, Values and Perspectives. In International Conference, New perspectives in Science Education, Edition 4, pp. 1-4.

Dadfar, 2001 - Dadfar, H. (2001). Intercultural Communication Theory and Practice. Institute of Technology. Linkoping University.

Delić, Bećirović, 2016 - Delić, H., Bećirović, S. (2016). Socratic Method as an Approach to Teaching. // European Researcher. Series A, Vol. (111), Is. 10, pp. 511-517. DOI: 10.13187/er.2016.111.511

Farena, 2016 - Farena, K. (2016). Interkulturalizam kroz komunikaciju u konfliktnim i asimetričnim odnosima. In Odjel za interdisciplinarne, talijanske I kulturološke studije, pp. 1-37.

Gualandi, 2015 - Gualandi, D.W. (2015). Intercultural understanding: What are we looking for and how do we assess what we find? In Working Papers Series. Interanational and Global issues for Research, 1-29.

Heinzman, 2009 - Heinzmann, S. (2009). Girls are better at language learning than boys: Do stereotypic beliefs about language learning contribute to girls' higher motivation to learn English in primary school? In VALS-ASLA (Swiss association of applied linguistics, 89, pp.19-36.

Jarcău, 2014 - Jarcău, M. (2014). Intercultural education important component of lifelong learning. Procedia - Social and Behavioral Sciences, 142, pp. 421-426.

Krieger, 2005 - Krieger, N. (2005). Experiences of discrimination: Validity and reliability of a self-report measure for population health research on racism and health. In Social Science and Medicine, Volume 61, Issue 7, pp. 1576-1596.

Liddicoat, Scarino, 2005 - Liddicoat, A.J., Scarino A. (2005). Teaching and Learning Languages. Curriculum Corporation Australia. Australia GEON Impact Printing Pty Ltd.

Martinson, Schulz, 2008 - Martinson, S.D., Schulz R.A. (2008). Transcultural German Studies. Bern: Peter Lang Pub.

Milot, 2006 - Milot, M. (2006). The religious dimension in intercultural education. In J. Keast (Ed.). Religious diversity and intercultural education: a reference book for schools, pp. 1320. Council of Europe.

Mlinarević, Nemet, 2010 - Mlinarević, V., Nemet M.B. (2010). Do future teachers possess intercultural competencies to work in extracurricular activities? Media Res. 2 nd International Scientific Conference, pp. 151-167.

Narayanan, 2007 - Narayanan, $R$. (2007). Do female students have higher motivation from male students in learning of English at the tertiary level? In Institute of Education Sciences ERIC.

NCCA, 2006 - National Council for Curriculum and Assessment (2006). Retrieved from https://www.ncca.ie/

Neuliep, 2005 - Neuliep, J.W. (2005). The Necessity of Intercultural Communication, Chapter 1. In Intercultural Communication, a Contextual Approach. Edition 3, pp. 1-37.

Patrascu, Allam, 2015 - Patrascu, E., Allam M. (2015). Role of Intercultural Education in Making Global World. In International Conference RCIC'15, pp. 279-286.

Piršl, 2011 - Piršl, E. (2011). Odgoj I obrazovanje za interkulturalnu kompetenciju. Pedagogijska istrazivanja, 8(1), pp. 53-70.

Qin, 2014 - Qin, X. (2014). Teaching Foreign Languages by Explaining Intercultural Misunderstanding. In Intercultural Communication Studies XXIII: 3, pp. 66-82.

Rajić, Prtljaga, 2013 - Rajić, A.G., Prtljaga J. (2013). Foreign language learning as a factor of intercultural tolerance. In Procedia-Social and Behavioral Sciences, 93, pp. 809-813.

Rizvić, Bećirović, 2017 - Rizvić, E., Bećirović, S., (2017). Willingness to Communicate in English as a Foreign Language in Bosnian-Herzegovinian EFL Context. // European Researcher, 8, (3), pp.224-235. DOI: 10.13187/er.2017.3.224

Ryan, Sercu, 2005 - Ryan, P., Sercu L. (2005). Familiarity and contacts with foreign cultures. M. Byram, A. Phipps (Eds.), Foreign Language Teachers and Intercultural Competence, pp.39-49.

Ryan, Sercu, 2003 - Ryan, P.M., Sercu L. (2003) Foreign language teachers and their role as mediators of language and culture. In Estudios de Linguistica Aplicada (pp.99-118).

Sablić et al., 2010 - Sablić, M., Škugor A. \& Malkić E. (2010). Education for Interculturalism. MEDIA RES 2nd International Scientific Conference (pp.89-104). 
Salgur, 2013 - Salgur, S. A. (2013). The Importance of the teacher in Intercultural Education. International Journal of Global Education-2013, volume 2, issue 1, pp. 1-5.

Savić, 2013 - Savić, V. (2013). Developing Intercultural Literacy in the Young Learner Classroom. In V. Savić \& I.C. Miladinović (Eds.) Integrating Culture and Language Teaching in TEYL, pp. 35-53.

Sercu, 2005 - Sercu, L. (2005). Foreign Language Teachers and Intercultural Competence Teacher. In M. Byram \& A. Phipps (Eds.) Foreign Language Teachers and Intercultural Competence, pp. 130-160.

Solhaug, Kristensen, 2016 - Solhaug, T., Kristensen N.N. (2016). Antecedents of Intercultural and cross national competence among Danish and Norwegian students in school? Paper presented for ECPR General Conference Prague.

Suchankova, 2014 - Suchankova, H. (2014). Developing Intercultural Competence during the Language Tuition. Procedia - Social and Behavioral Science, 116, pp. 1439-1443.

UNESCO, 2002 - UNESCO (2002). Universal Declaration on Cultural Diversity, Published: United Nations Educational, Scientific and Cultural Organization, Paris (France). Retrieved from: http://unesdoc.unesco.org/images/o012/o01271/127162e.pdf

Yaman, Bećirović, 2016 - Yaman, A., Bećirović, S. (2016). Learning English and Media Literacy. In Imperial Journal of Interdisciplinary Research (IJIR), Vol. 2, Is. 6, pp. 660-663.

Zilliacus, Holm, 2009 - Zilliacus, H., Holm G. (2009). Multicultural education and intercultural education: Is there is a difference? In M. Talib, J. Loima, H. Paavola, \& S. Patrikainen (Eds.). Dialogues on Diversity and Global Education (pp. 11-28). 